\title{
HABITAT ANALYSIS OF STORK-BILLED KINGFISHER (PELARGOPSIS CAPENSIS) AND PIED KINGFISHER (CERYLE RUDIS) AT THE CHITTAGONG UNIVERSITY CAMPUS, BANGLADESH
}

\author{
J. K. Biswas ${ }^{*}$, N. J. Sarker ${ }^{1}$, M. M. Rahman and M. F. Ahsan \\ Department of Zoology, University of Chittagong, Chittagong-4331, Bangladesh
}

\begin{abstract}
The habitat analysis of stork-billed kingfisher (Pelargopsis capensis Linnaeus, 1766) and pied kingfisher (Ceryle rudis Linnaeus, 1758) was done at the Chittagong University Campus, Chittagong, Bangladesh during January 2011 to December 2013. The both kingfisher species used five types of habitat (pond, lake, stream, agricultural land/channel and tree), of which trees were used maximum (43.23\%) and agricultural lands/channels were minimum $(3.76 \%)$ by stork-billed kingfisher; whereas pied kingfisher spent the highest time (40.66\%) in the streams and the lowest (11.67\%) in the agricultural lands/channels. Four types of perching places (fence, wire, bamboo and tree) were used by both kingfisher species, of which trees were used maximum (68.89\%) and wires minimum $(2.78 \%)$ by stork-billed kingfisher; while pied kingfisher spent the highest (53.43\%) time on fences and the lowest $(4.78 \%)$ on wires.
\end{abstract}

Key words: Habitat analysis, stork-billed kingfisher, pied kingfisher.

\section{INTRODUCTION}

The stork-billed kingfisher (Pelargopsis capensis) is an uncommon resident bird in Bangladesh (Khan 1982), and occurs in the ponds and wetlands of all civil administrative divisions (Islam and Kamruzzaman 2008), and well distributed in India, Nepal, Sikkim, Bangladesh, Thailand, Myanmar and Indonesia (Ali 1996 and Ali and Ripley 1970). The pied kingfisher (Ceryle rudis) is a common inhabitant bird in Bangladesh and occurs in the rivers and lakes of all Divisions (Khan 1982 and Islam and Kamruzzaman 2008). They are well distributed in Bangladesh, India, Pakistan, Sri Lanka, Myanmar, Nepal, Sikkim, and Bhutan except the Maldives and Kerala (Ali 1996, Ali and Ripley 1970).

The stork-billed kingfisher was reported by Begbie (1906) from Cawnpore in India; whereas Kulshreshtha and Vyas (1989) described it from eastern Rajasthan (India). But the habitat preferences of stork-billed kingfisher and pied kingfisher have not yet been studied in Bangladesh and other countries in the world. Therefore, the present study was carried out to analyse the habitats of

\footnotetext{
* Corresponding author: jadabbiswas@yahoo.com. 1Department of Zoology, University of
} Dhaka, Dhaka-1000, Bangladesh

(C) 2015 Zoological Society of Bangladesh DOI: 10.3329/bjz.v43i2.27396 
stork-billed kingfisher (Pelargopsis capensis) and pied kingfishers (Ceryle rudis) at the Chittagong University Campus.

\section{MATERIAL AND METHODS}

Study area: The present study was carried out during January 2011 to December 2013 in the Chittagong University Campus (CUC) (Fig. 1); which is situated at the village Fatepur under Hathazari upazila of Chittagong district in Bangladesh and the area lies from $22^{\circ} 27^{\prime} 30^{\prime \prime}$ ' and $22^{\circ} 29^{\prime} 0^{\prime \prime}$ ' North Latitudes to $91^{\circ} 46^{\prime} 30^{\prime \prime}$ and 91 $47^{\circ} 45^{\prime \prime}$ East Longitudes (Ahsan and Khanom 2005). The CUC covers an area of 709.79 hectares $(1,753.88$ acres) of land, which is mainly hilly. The $72 \%$ of the area is hilly and consists of small hills and the remaining is either valleys or plain land and the height of the valleys is almost $15-90 \mathrm{~m}$ above mean sea level (Islam et al. 1979). Out of total hilly area, about 30\% of hills are higher than $70 \mathrm{~m}$ whereas $60 \%$ of them are less than $30 \mathrm{~m}$ high (Islam et al. 1979). The study area was divided into eight distinct sites on the basis of the significance of locations for observing birds to make expediency of the field work.

Site 1. Aquatic bodies close to the staff colony near Science Faculty Teacher Lounge to Botanical Garden: The most prominent attributes of this site is hilly area with small to medium streams, lakes, ponds and diversified plants including Aam (Mangifera indica), Bot (Ficus benghalensis), Boroi (Zizyphus mauritiana), Coconut (Cocos nucifera), Jhau (Casuarina equisitifolia), Koroi (Albizzia spp.), Kanthal (Artocarpus heterophyllus), Jam (Syzygium cumini), Palash (Butea monosperma), and Shimul (Salmalia spp.), etc. (Ahsan and Khanom 2005).

Site 2. Aquatic bodies of north site of the Shaheed Abdur Rab Hall to Lake near to the west site of Arts Faculty: It is a natural shallow water-body situated just north site of the Shaheed Abdur Rab Hall and west site of the Arts Faculty. This site is also characterised by small hills and diversified plants. The major plants are Akashmoni (Acacia moniliformis), Eucalyptus (Eucalyptus spp.), Koroi (Albizzia spp.), Garjan (Dipterocarpus spp.), Kanthal (Artocarpus heterophyllus), Jam (Syzygium cumini), Palash (Butea monosperma), Shegun (Tectona grandis), Bot (Ficus bengalensis), Shimul (Salmalia spp.), etc. 


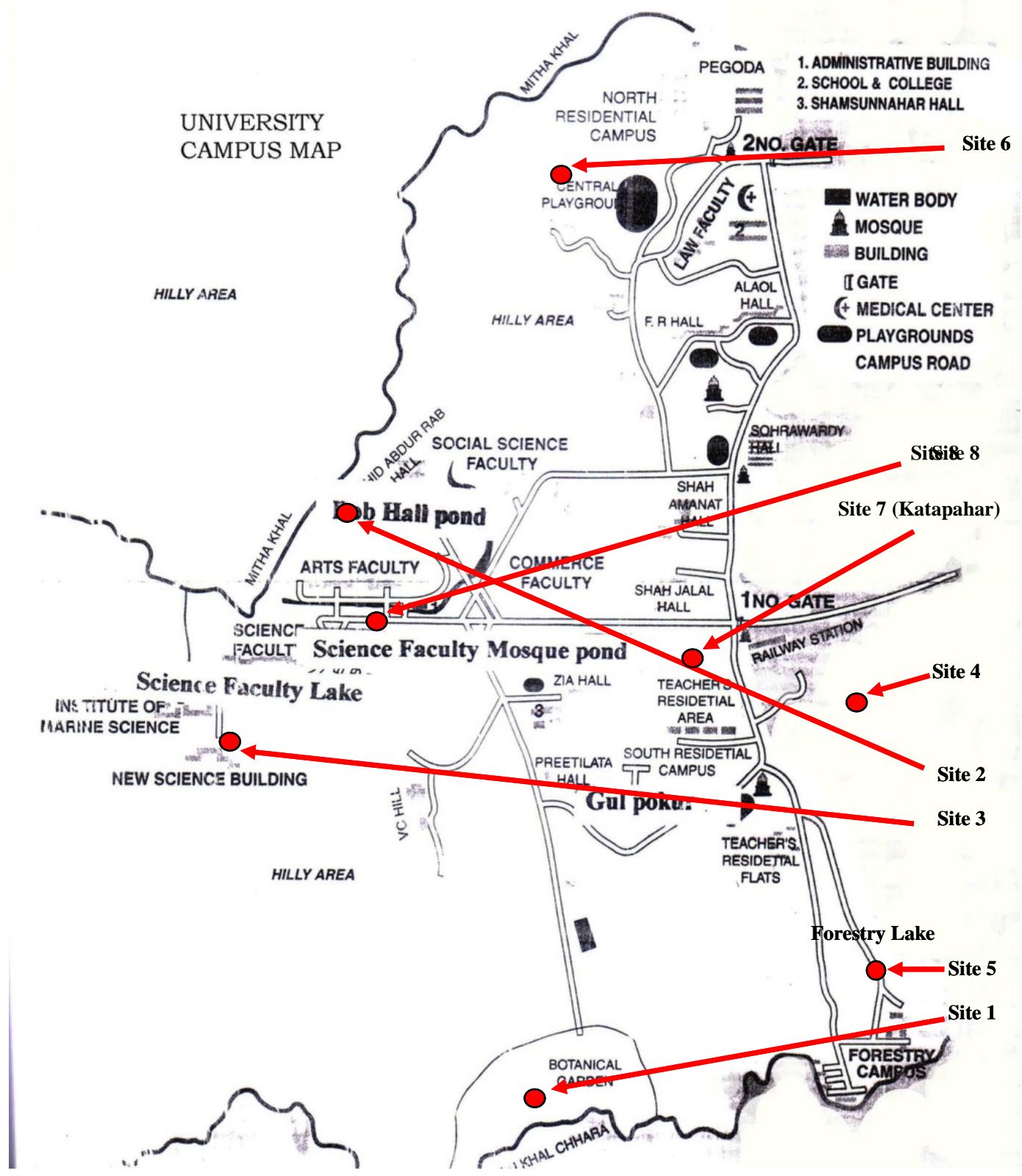

Fig. 1. Map of the study sites at the Chittagong University Campus.

Site 3. Aquatic bodies near Science Faculty to Institute of Marine Science and Fisheries: This site comprises almost plain and level area. The lake usually contains little water and this site is also separated by various agricultural lands. The important plants are Koroi (Albizzia spp.), Garjan (Dipterocarpus spp.), Jarul (Lagerstroemia speciosa), Shegun (Tectona grandis), Palash (Butea monosperma), etc. (Ahsan and Khanom 2005). 
Site 4. Aquatic bodies near to the University Railway Station: This site is basically located to the east of the Chittagong University Campus and including shallow to medium level of water-bodies and not attributed by diversified plants. Aam (Mangifera indica) and Koroi (Albizzia spp.) are important plant species in this site.

Site 5. Aquatic bodies near to the west sites of the Institute of Forestry and Environmental Science of Chittagong University (IFESCU): The maximum areas of this site are almost plain, but have some small hills comprising gentle slopes. There is a lake, a stream and two ponds with shallow to medium water levels covered by diversified trees. The major trees of this site are Akashmoni (Acacia moniliformis), Coconut (Cocos nucifera), Eucalyptus (Eucalyptus spp.), Koroi (Albizzia spp.), Garjan (Dipterocarpus spp.), Kanthal (Artocarpus heterophyllus), Shegun (Tectona grandis), Debdaru (Polyalthia longifolia), etc. (Ahsan and Khanom 2005).

Site 6. Aquatic bodies close to the Central Playground: This site is almost flat area including adjacent hillocks with moderate slopes and containing important plant species including Palash (Butea monosperma), Koroi (Albizzia spp.), Jarul (Lagerstroemia speciosa), Akashmoni (Acacia moniliformis), Bandar lathi/Sonalu (Cassia fistula), Eucalyptus (Eucalyptus spp.), Amloki (Phyllanthus embelica), Shimul (Salmalia spp.), etc. (Ahsan and Khanom 2005).

Site 7. Katapahar and its adjacent areas: It is a more or less hilly area with small to medium high hills and included small plain land adjacent to the roadside. The major plants consist of Koroi (Albizzia spp.), Garjan (Dipterocarpus spp.), Shegun (Tectona grandis), Bandar lathi/Sonalu (Cassia fistula) and Eucalyptus (Eucalyptus spp.) (Ahsan and Khanom 2005).

Site 8. Shaheed Miner to Science Faculty Compound: This area is also almost plain and leveled and including Shaheed Miner, Administrative Building, Arts Faculty and Science Faculty, but the Engineering Faculty and Central Library is on gentle slope. Usually secondary vegetation like Jarul (Lagerstroemia speciosa), Koroi (Albizzia spp.), Palash (Butea monosperma), Shegun (Tectona grandis), Garjan (Dipterocarpus spp.), etc. are occurred on the both sides of roads (Ahsan and Khanom 2005).

Equipments: The equipments used in present study were one pair of binocular (Bushnell, $90 \times$ 90; $140 \mathrm{M} / 2000 \mathrm{M}$ ), a field guide (Grimmett et al. 1999), one camera (Nikon COOLPIX, P 520; 42 X optical zoom, 18.1 megapixel), a stopwatch, thermometer, $\mathrm{pH}$ meter and Secchi disk. Measuring tape, electrical balance, standard hydrometer, ASTM No. $152 \mathrm{H}$ with Bouyocos scale in g/l, $1000 \mathrm{ml}$ sedimentation cylinder, hot plate, electrical oven, metal dispersing unit, $600 \mathrm{ml}$ tall beaker, and wash bottle, etc. Some reagents $[30 \%$ hydrogen peroxide, 5\% sodium hexametaphosphate (Calgon) and Amyl alcohol] were used to determine the soil texture collected from feeding ground and breeding spots of kingfisher species in the study area. 
Observation techniques: The habitats used by kingfisher species were evaluated by categorizing the habitat into different types like pond, lake, stream, agricultural land/channel and tree. Data were collected by direct observation (during $0700 \mathrm{~h}$ to $1900 \mathrm{~h}$ in summer, but 0700 to $1730 \mathrm{~h}$ in winter) followed by scan sampling method (based on 5 minutes intervals) of Altmann (1974). The perching places used by the study species were also observed and noted during resting and/or perching, preying and feeding. The height of the perching places were observed visually, estimated with measuring tape and recorded in the data sheet as well as the time spent in preying with the particular height of perching places was also counted by a digital stopwatch and noted carefully. Different species of plants used by two kingfisher species were observed and the height of the activity place and total height of the plants were also measured. The water parameters like water temperature, $\mathrm{pH}$ and turbidity were recorded respectively with thermometer, $\mathrm{pH}$ meter and Secchi disk. Soils were collected from both the feeding and breeding sites of kingfisher species and physical compositions were analysed by hydrometer method followed by Imamul Huq and Alam (2005).

\section{RESULTS AND DISCUSSION}

Overall habitat used: The stork-billed kingfishers (Pelargopsis capensis) used five types of habitat: (1) pond, (2) lake, (3) stream, (4) agricultural land/channel and (5) tree; of which trees were used maximum $(43.23 \%)$ and agricultural lands/channels minimum (3.76\%) (Table 1; Fig. 2); and the pied kingfishers (Ceryle rudis) also used the same five habitats like stork-billed kingfishers, but they spent the highest time $(40.66 \%)$ in the streams and the lowest $(11.67 \%)$ in the agricultural lands/channels during the study period (Table 1; Fig. 2). The habitats used by the two species did not vary significantly $(\mathrm{F}=3.26, \mathrm{df}=4, \mathrm{p}=1.00)$; whereas there were significant differences in the use of different habitats by both kingfisher species independently (stork-billed kingfisher: $\mathrm{t}=3.04, \mathrm{df}=4, \mathrm{p}=0.04$; pied kingfisher: $\mathrm{t}=3.42, \mathrm{df}=4, \mathrm{p}=0.03$ ).

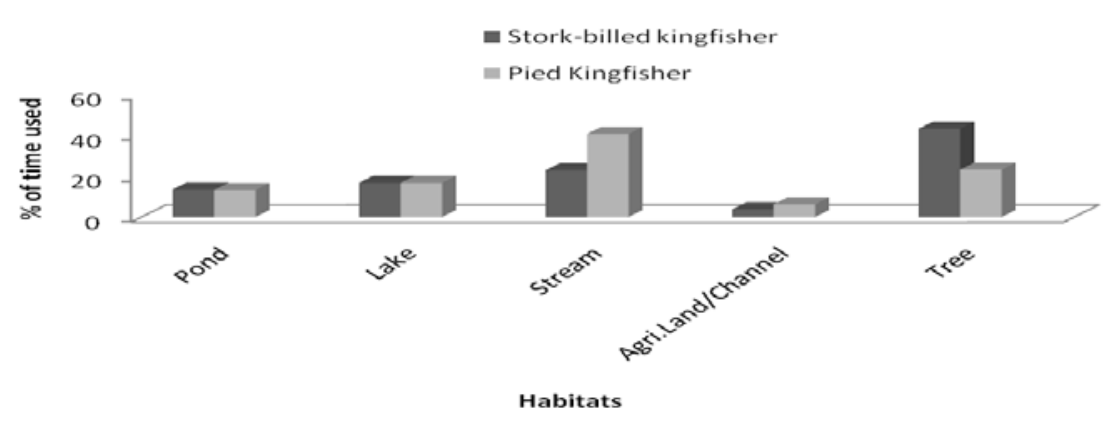

Fig. 2. Habitats preference by two species of kingfishers. 
Table 1. Habitat preferences of stork-billed kingfisher and pied kingfisher at the CUC during the three years between January 2011 and December 2013) (\% presented within brackets).

\begin{tabular}{|c|c|c|c|c|c|c|c|c|c|c|c|c|}
\hline \multirow[t]{2}{*}{$\mathbf{M}$} & \multicolumn{2}{|c|}{$\begin{array}{l}\text { Pond } \\
\text { (Scan) }\end{array}$} & \multicolumn{2}{|c|}{$\begin{array}{l}\text { Lake } \\
\text { (Scan) }\end{array}$} & \multicolumn{2}{|c|}{$\begin{array}{l}\text { Stream } \\
\text { (Scan) }\end{array}$} & \multicolumn{2}{|c|}{$\begin{array}{l}\text { Agricultural land/channel } \\
\text { (Scan) }\end{array}$} & \multicolumn{2}{|c|}{$\begin{array}{l}\text { Tree } \\
\text { (Scan) }\end{array}$} & \multicolumn{2}{|c|}{$\begin{array}{l}\text { Total } \\
\text { (Scan) }\end{array}$} \\
\hline & SBK & PK & SBK & PK & SBK & PK & SBK & PK & SBK & PK & SBK & PK \\
\hline Jan & $\begin{array}{c}16 \\
(1.06)\end{array}$ & $\begin{array}{c}18 \\
(1.13)\end{array}$ & $\begin{array}{c}21 \\
(1.39)\end{array}$ & $\begin{array}{c}23 \\
(1.44)\end{array}$ & $\begin{array}{c}28 \\
(1.85)\end{array}$ & $\begin{array}{c}49 \\
(3.07)\end{array}$ & $\begin{array}{c}5 \\
(0.33)\end{array}$ & $\begin{array}{c}10 \\
(0.63)\end{array}$ & $\begin{array}{c}55 \\
(3.63)\end{array}$ & $\begin{array}{c}30 \\
(1.88)\end{array}$ & $\begin{array}{c}125 \\
(8.25)\end{array}$ & $\begin{array}{c}130 \\
(8.15)\end{array}$ \\
\hline $\mathrm{Feb}$ & $\begin{array}{c}16 \\
(1.06)\end{array}$ & $\begin{array}{c}16 \\
(1.00)\end{array}$ & $\begin{array}{c}20 \\
(1.32)\end{array}$ & $\begin{array}{c}21 \\
(1.32)\end{array}$ & $\begin{array}{c}30 \\
(1.98)\end{array}$ & $\begin{array}{c}50 \\
(3.31)\end{array}$ & $\begin{array}{c}3 \\
(0.20)\end{array}$ & $\begin{array}{c}8 \\
(0.50)\end{array}$ & $\begin{array}{c}55 \\
(3.63)\end{array}$ & $\begin{array}{c}34 \\
(2.13)\end{array}$ & $\begin{array}{c}124 \\
(8.18)\end{array}$ & $\begin{array}{c}129 \\
(8.08)\end{array}$ \\
\hline Mar & $\begin{array}{c}19 \\
(1.25)\end{array}$ & $\begin{array}{c}18 \\
(1.13)\end{array}$ & $\begin{array}{c}23 \\
(1.52)\end{array}$ & $\begin{array}{c}21 \\
(1.32)\end{array}$ & $\begin{array}{c}30 \\
(1.98)\end{array}$ & $\begin{array}{c}60 \\
(3.76)\end{array}$ & $\begin{array}{c}5 \\
(0.33)\end{array}$ & $\begin{array}{c}8 \\
(0.50)\end{array}$ & $\begin{array}{c}62 \\
(4.09)\end{array}$ & $\begin{array}{c}35 \\
(2.19)\end{array}$ & $\begin{array}{c}139 \\
(9.17)\end{array}$ & $\begin{array}{c}142 \\
(8.90)\end{array}$ \\
\hline Apr & $\begin{array}{c}20 \\
(1.32)\end{array}$ & $\begin{array}{c}17 \\
(1.07)\end{array}$ & $\begin{array}{c}25 \\
(1.65)\end{array}$ & $\begin{array}{c}26 \\
(1.63)\end{array}$ & $\begin{array}{c}32 \\
(2.11)\end{array}$ & $\begin{array}{c}55 \\
(3.45)\end{array}$ & $\begin{array}{c}7 \\
(0.46)\end{array}$ & $\begin{array}{c}9 \\
(0.56)\end{array}$ & $\begin{array}{c}65 \\
(4.29)\end{array}$ & $\begin{array}{c}37 \\
(2.32)\end{array}$ & $\begin{array}{c}149 \\
(9.83)\end{array}$ & $\begin{array}{c}144 \\
(9.02)\end{array}$ \\
\hline May & $\begin{array}{c}21 \\
(1.39)\end{array}$ & $\begin{array}{c}21 \\
(1.32)\end{array}$ & $\begin{array}{c}26 \\
(1.72)\end{array}$ & $\begin{array}{c}24 \\
(1.50)\end{array}$ & $\begin{array}{c}35 \\
(2.31)\end{array}$ & $\begin{array}{c}58 \\
(3.63)\end{array}$ & $\begin{array}{c}6 \\
(0.40)\end{array}$ & $\begin{array}{c}8 \\
(0.50)\end{array}$ & $\begin{array}{c}60 \\
(3.96)\end{array}$ & $\begin{array}{c}35 \\
(2.19)\end{array}$ & $\begin{array}{c}148 \\
(9.77)\end{array}$ & $\begin{array}{c}146 \\
(9.15)\end{array}$ \\
\hline June & $\begin{array}{c}17 \\
(1.12)\end{array}$ & $\begin{array}{c}16 \\
(1.00)\end{array}$ & $\begin{array}{c}25 \\
(1.65)\end{array}$ & $\begin{array}{c}25 \\
(1.57)\end{array}$ & $\begin{array}{c}30 \\
(1.98)\end{array}$ & $\begin{array}{c}53 \\
(3.32)\end{array}$ & $\begin{array}{c}6 \\
(0.40)\end{array}$ & $\begin{array}{c}11 \\
(0.69)\end{array}$ & $\begin{array}{c}55 \\
(3.63)\end{array}$ & $\begin{array}{c}30 \\
(1.88)\end{array}$ & $\begin{array}{c}133 \\
(8.78)\end{array}$ & $\begin{array}{c}135 \\
(8.46)\end{array}$ \\
\hline July & $\begin{array}{c}15 \\
(0.99)\end{array}$ & $\begin{array}{c}17 \\
(1.07)\end{array}$ & $\begin{array}{c}21 \\
(1.39)\end{array}$ & $\begin{array}{c}23 \\
(1.44)\end{array}$ & $\begin{array}{c}28 \\
(1.85)\end{array}$ & $\begin{array}{c}55 \\
(3.45)\end{array}$ & $\begin{array}{c}5 \\
(0.33)\end{array}$ & $\begin{array}{c}7 \\
(0.44)\end{array}$ & $\begin{array}{c}60 \\
(3.96)\end{array}$ & $\begin{array}{c}29 \\
(1.82)\end{array}$ & $\begin{array}{c}129 \\
(8.51)\end{array}$ & $\begin{array}{c}131 \\
(8.21)\end{array}$ \\
\hline Aug & $\begin{array}{c}18 \\
(1.19)\end{array}$ & $\begin{array}{c}20 \\
(1.25)\end{array}$ & $\begin{array}{c}23 \\
(1.52)\end{array}$ & $\begin{array}{c}24 \\
(1.50)\end{array}$ & $\begin{array}{c}30 \\
(1.98)\end{array}$ & $\begin{array}{c}58 \\
(3.63)\end{array}$ & $\begin{array}{c}4 \\
(0.26)\end{array}$ & $\begin{array}{c}8 \\
(0.50)\end{array}$ & $\begin{array}{c}50 \\
(3.30)\end{array}$ & $\begin{array}{c}27 \\
(1.69)\end{array}$ & $\begin{array}{c}125 \\
(8.25)\end{array}$ & $\begin{array}{c}137 \\
(8.58)\end{array}$ \\
\hline Sep & $\begin{array}{c}19 \\
(1.25)\end{array}$ & $\begin{array}{c}20 \\
(1.25)\end{array}$ & $\begin{array}{c}21 \\
(1.39)\end{array}$ & $\begin{array}{c}24 \\
(1.50)\end{array}$ & $\begin{array}{c}26 \\
(1.72)\end{array}$ & $\begin{array}{c}53 \\
(3.32)\end{array}$ & $\begin{array}{c}4 \\
(0.26)\end{array}$ & $\begin{array}{c}7 \\
(0.44)\end{array}$ & $\begin{array}{c}48 \\
(3.17)\end{array}$ & $\begin{array}{c}27 \\
(1.69)\end{array}$ & $\begin{array}{c}118 \\
(7.79)\end{array}$ & $\begin{array}{c}131 \\
(8.21)\end{array}$ \\
\hline Oct & $\begin{array}{c}15 \\
(0.99)\end{array}$ & $\begin{array}{c}16 \\
(1.00)\end{array}$ & $\begin{array}{c}17 \\
(1.12)\end{array}$ & $\begin{array}{c}20 \\
(1.25)\end{array}$ & $\begin{array}{c}26 \\
(1.72)\end{array}$ & $\begin{array}{c}52 \\
(3.26)\end{array}$ & $\begin{array}{c}5 \\
(0.33)\end{array}$ & $\begin{array}{c}8 \\
(0.50)\end{array}$ & $\begin{array}{c}50 \\
(3.30)\end{array}$ & $\begin{array}{c}25 \\
(1.57)\end{array}$ & $\begin{array}{c}113 \\
(7.46)\end{array}$ & $\begin{array}{c}121 \\
(7.58)\end{array}$ \\
\hline Nov & $\begin{array}{c}16 \\
(1.06)\end{array}$ & $\begin{array}{c}15 \\
(0.94)\end{array}$ & $\begin{array}{c}15 \\
(0.99)\end{array}$ & $\begin{array}{c}18 \\
(1.13)\end{array}$ & $\begin{array}{c}25 \\
(1.65)\end{array}$ & $\begin{array}{c}55 \\
(3.45)\end{array}$ & $\begin{array}{c}5 \\
(0.33)\end{array}$ & $\begin{array}{c}6 \\
(0.38)\end{array}$ & $\begin{array}{c}50 \\
(3.30)\end{array}$ & $\begin{array}{c}32 \\
(2.01)\end{array}$ & $\begin{array}{c}111 \\
(7.33)\end{array}$ & $\begin{array}{c}126 \\
(7.89)\end{array}$ \\
\hline Dec & $\begin{array}{c}12 \\
(0.79)\end{array}$ & $\begin{array}{c}17 \\
(1.07)\end{array}$ & $\begin{array}{c}16 \\
(1.06)\end{array}$ & $\begin{array}{c}17 \\
(1.07)\end{array}$ & $\begin{array}{c}26 \\
(1.72)\end{array}$ & $\begin{array}{c}51 \\
(3.20)\end{array}$ & $\begin{array}{c}2 \\
(0.13)\end{array}$ & $\begin{array}{c}9 \\
(0.56)\end{array}$ & $\begin{array}{c}45 \\
(2.97)\end{array}$ & $\begin{array}{c}30 \\
(1.88)\end{array}$ & $\begin{array}{c}101 \\
(6.67)\end{array}$ & $\begin{array}{c}124 \\
(7.77)\end{array}$ \\
\hline Total & $\begin{array}{c}204 \\
(13.47)\end{array}$ & $\begin{array}{c}211 \\
(13.22)\end{array}$ & $\begin{array}{c}253 \\
(16.70)\end{array}$ & $\begin{array}{c}266 \\
(16.67)\end{array}$ & $\begin{array}{c}346 \\
(22.84)\end{array}$ & $\begin{array}{c}649 \\
(40.66)\end{array}$ & $\begin{array}{c}57 \\
(3.76)\end{array}$ & $\begin{array}{c}99 \\
(6.20)\end{array}$ & $\begin{array}{c}655 \\
(43.23)\end{array}$ & $\begin{array}{c}369 \\
(23.12)\end{array}$ & $\begin{array}{l}1515 \\
(100)\end{array}$ & $\begin{array}{l}1596 \\
(100)\end{array}$ \\
\hline
\end{tabular}

M : Months; SBK : Stork-billed kingfisher; PK: Pied kingfisher 
Stork-billed kingfisher spent the highest time in April (9.83\%) and the lowest in December $(6.67 \%)$ using different habitats, whereas pied kingfisher occupied the habitats maximum $(9.15 \%)$ in May and minimum $(7.58 \%)$ in October. Monthly time spent by two species differed significantly $(\mathrm{F}=7.16$, df $=11, \mathrm{p}=$ 0.0014) (Table 1; Fig. 3).

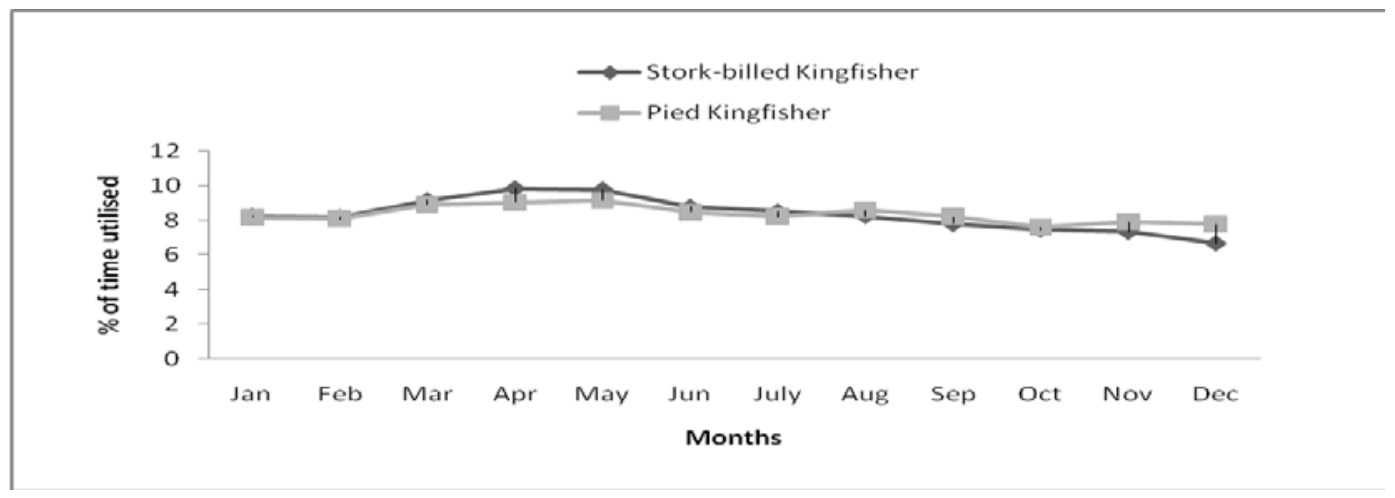

Fig. 3. Monthly variation in habitat used by two species of kingfishers.

Several factors have been reported that influence the habitat use of kingfishers like, diet (Libois and Laudelout 2004), depth of the water bodies (Monadjem 1996), perch height (Monadjem et al. 1994) and water quality (Douthwaite 1982). On the other hand, environmental conditions, inter-specific competition, and other factors including morphology, behaviour, capability to find food and shelter, structural attribute of landscape, foraging and nesting opportunities usually participate in habitat selection (Cody 1985).

Islam and Kamruzzaman (2008) reported that the stork-billed kingfisher predominantly occurred in the forest streams, slow-moving rivers, irrigation channels, backwaters, tidal creeks and even the ponds; whereas Ali (1996) described that they mainly used jungle pools, swampy glades, and even the mangrove and tidal creeks. Fry et al. (1992) reported that stork-billed kingfisher primarily occupied habitats near lakes, rivers or coasts; while Ali and Ripley (1970) described that they chiefly used the streams; large, placid, heavily shaded forest streams; irrigation channel in well-wooded country and coastal backwaters.

The pied kingfisher mostly exploited freshwaters like streams, canals, rivers, ponds, reservoirs, flooded ditches, tidal creeks and the intertidal pools (Islam and Kamruzzaman 2008); whereas Hockey et al. (2005) reported that they can live at any water body (including streams, rivers, lakes, temporary pans, estuaries, temporarily flooded areas and rocky coasts) if there are small fish. Ali (1996) mentioned that they chiefly occurred in rivers, jheels, irrigation tanks and tidal creeks; while Ali and Ripley (1970) illustrated that the pied kingfisher predominantly used slow-moving rivers, streams, canals, jheels, irrigation reservoirs, village tanks and flooded ditches even occasionally used the tidal creeks and intertidal rock pools on the seashore. 
Pond: The pond is a body of standing water that is usually smaller than a lake and may be either natural or man-made, usually contains shallow water with marsh and aquatic plants, and animals (John 1986). Among the habitats stork-billed kingfisher spent $13.47 \%$ time in pond, whereas pied kingfisher used $13.22 \%$ of their diurnal time in pond (Table 1). Ponds were the highest $(1.39 \%)$ used in May by stork-billed kingfisher and the lowest $(0.79 \%)$ in December, while pied kingfisher also used pond most (1.32\%) in May and the least $(0.94 \%)$ in November (Table 1; Fig. 4). The pond used (in terms of time spent) by both kingfisher species in different months were not similar to each other and varied significantly $(\mathrm{F}=3.52, \mathrm{df}=11, \mathrm{p}=0.02)$.

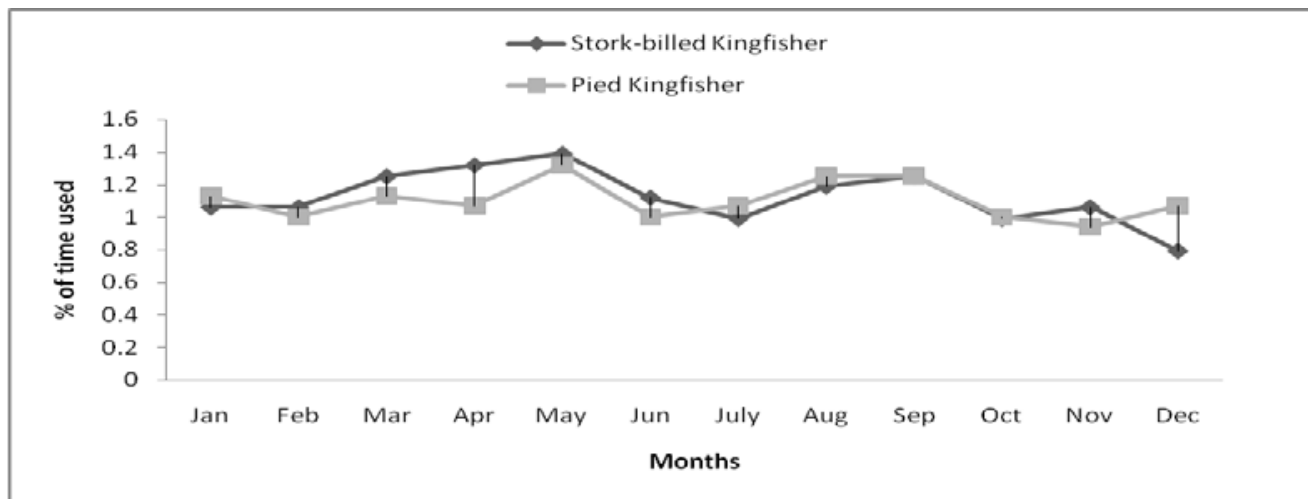

Fig. 4. Monthly variation of ponds used by two species of kingfishers.

Lake: Lake is a body with relatively still water and the area may be 2 ha ( 5 acres) or more often contrasted with river or stream (Williams et al. 2004). Storkbilled kingfisher used $16.70 \%$ of their diurnal time in lake but pied kingfisher spent $14.67 \%$ time (Table 1). Stork-billed kingfisher used the lake highest time in May $(1.72 \%)$ and the lowest in November $(0.99 \%)$, whereas lake was maximum used by pied kingfisher in April (1.63\%) and minimum in December $(1.07 \%)$ (Table 1; Fig. 5). The lake used by both kingfisher species during the study period varied significantly between them $(\mathrm{F}=11.81, \mathrm{df}=11, \mathrm{p}=0.00014)$.

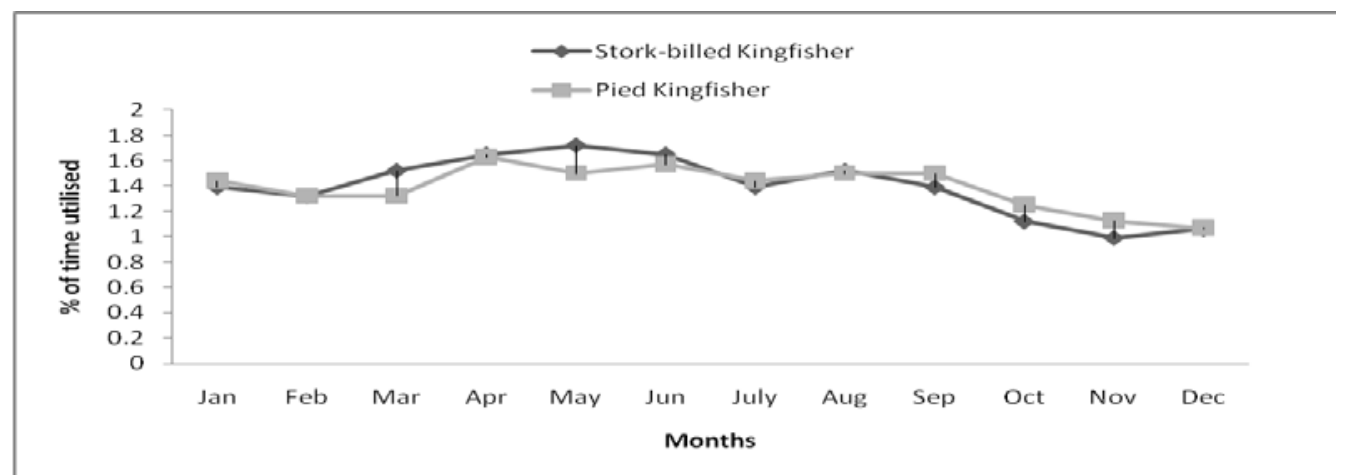

Fig. 5. Monthly variation of lakes used by two species kingfishers. 
Stream: The stream is a body with flowing water and generally applied to the water following in a natural channel which is distinct from a canal as well as it is also applied to the water flowing in any channel, natural or artificial (Meinzer 1923). Stream was one of the significant habitats for kingfishers in the study sites, of which the stork-billed kingfisher exploited $22.84 \%$ of diurnal time in streams, and the pied kingfisher used $40.66 \%$ of their time (Table 1). The streams were maximum $(2.31 \%)$ used in May by stork-billed kingfisher and the minimum $(1.65 \%)$ in November, while pied kingfisher used the streams most $(3.76 \%)$ in March and the least (3.07\%) in January (Table 1; Fig. 6). The streams used by both kingfisher species in different months varied significantly $(\mathrm{F}=$ $3.13, \mathrm{df}=11, \mathrm{p}=0.04)$.

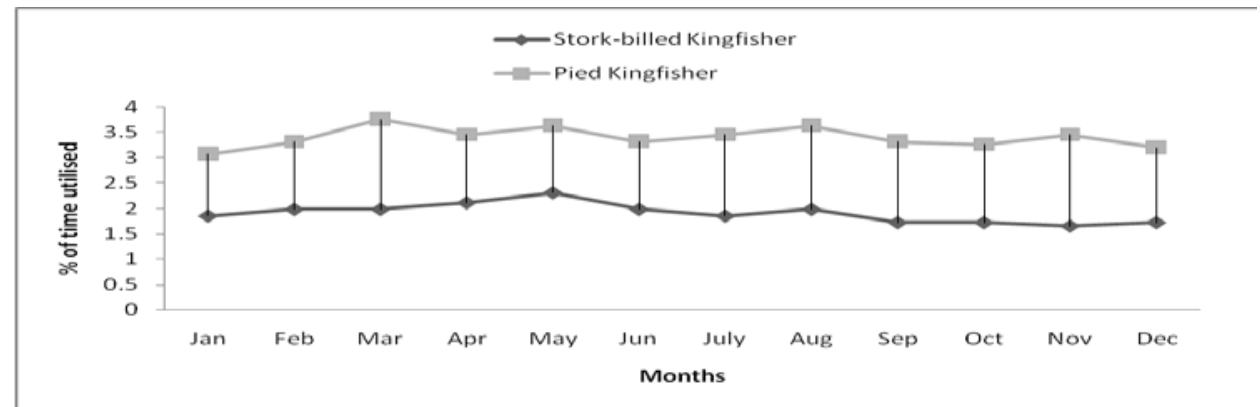

Fig. 6. Monthly variation of streams used by two species of kingfishers.

Agricultural land/channel: The stork-billed kingfisher and pied kingfisher were reported from irrigation channel by several authors (e.g., like Ali 1996, Ali and Ripley 1970). Stork-billed kingfisher used $3.76 \%$ of diurnal time in agricultural lands/channels and pied kingfisher used $6.20 \%$ time (Table 1). In the study sites, stork-billed kingfisher used the agricultural lands/channels most in April $(0.46 \%)$ and the least in December $(0.13 \%)$, whereas pied kingfisher used the highest time in June $(0.69 \%)$ and the lowest in November $(0.38 \%)$ (Table 1; Fig. 7). The agricultural lands used by both kingfishers species in different months did not vary significantly $(F=1.49$, $\mathrm{df}=11, \mathrm{p}=0.26)$.

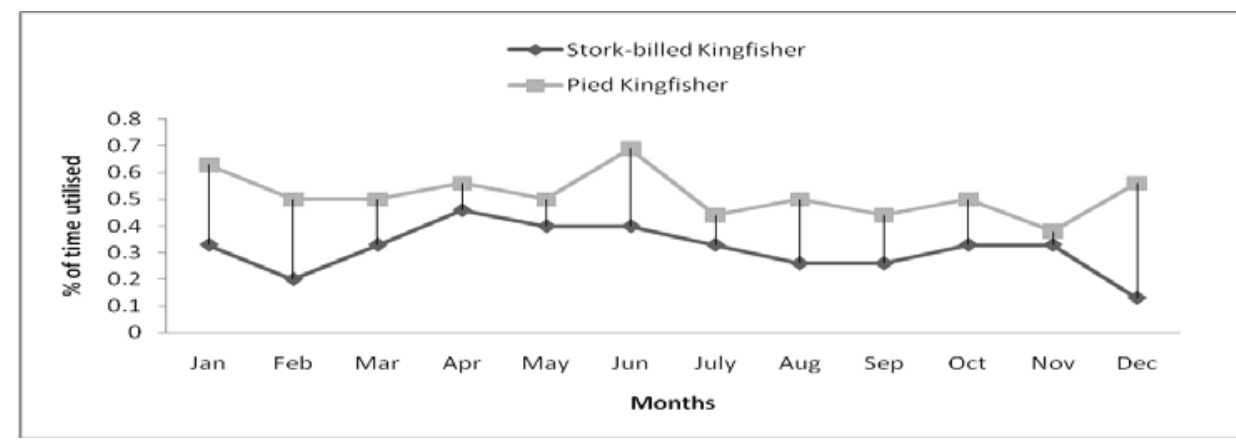

Fig. 7. Monthly variation of agricultural land/channel used by two species of kingfishers. 
Tree: Stork-billed kingfisher used $43.23 \%$ of their diurnal time in trees, while the pied kingfisher spent $23.12 \%$ time (Table 1 ). The trees was maximum used by stork-billed kingfisher in April (4.29\%) and minimum in December (2.97\%), whereas pied kingfisher used the trees most also in April $(2.32 \%)$ and the least in October (1.57\%) (Table 1; Fig. 8). Monthly time used by the two kingfisher species in the trees varied statistically significantly $(\mathrm{F}=4.2, \mathrm{df}=11, \mathrm{p}=0.01)$.

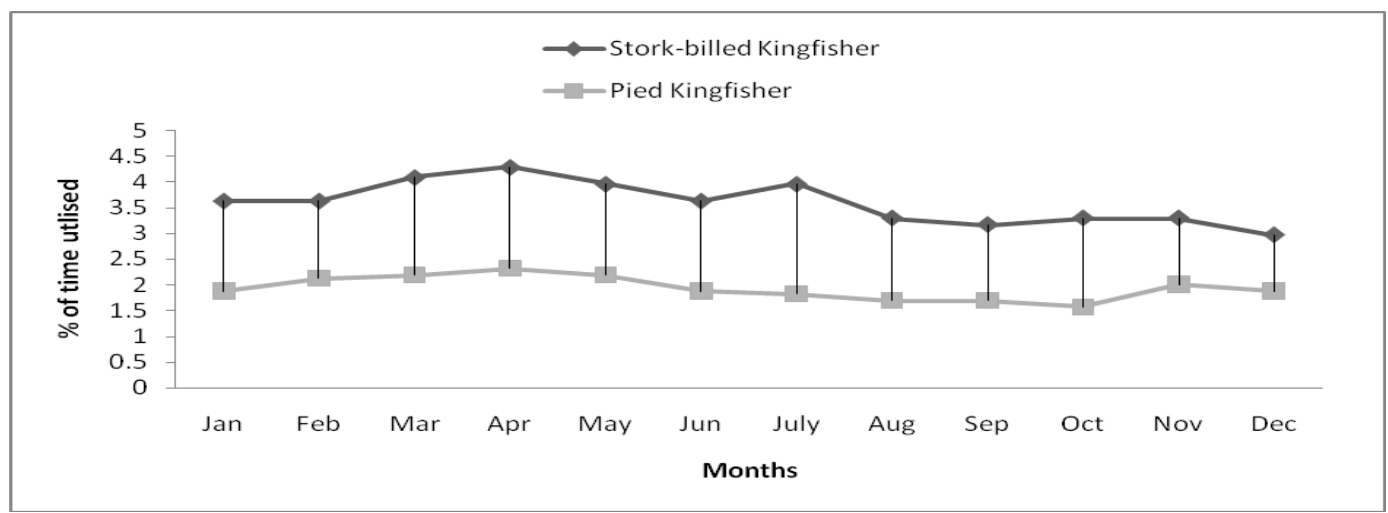

Fig. 8. Monthly variation of trees used by two species of kingfishers.

Perching places: The both kingfisher species used different perching places (fence, wire, bamboo and tree) during resting, diving and feeding (Table 2). Stork-billed kingfisher spent the highest (68.89\%) time in trees and the lowest $(2.78 \%)$ on wires, whereas pied kingfisher spent the maximum $(53.43 \%)$ time on fences and the minimum (4.78\%) also on wires (Table 2). The perching places used by the both kingfisher species did not differ significantly $(F=6.78$, df $=3, p$ $=0.08$ ). The stork-billed kingfisher usually preferred to perch in plants covered sites overhanging the water bodies, whereas the pied kingfisher used different perches during foraging (Islam and Kamruzzaman 2008). The pied kingfisher commonly found as perched together or independently on a desired rock or stake close to the water-bodies (Ali 1996, Ali and Ripley 1970).

Table 2. Variation of perching height of two species of kingfishers at the CUC.

\begin{tabular}{lcccc}
\hline \multirow{2}{*}{$\begin{array}{c}\text { Perching } \\
\text { Place }\end{array}$} & \multicolumn{2}{c}{ Stork-billed kingfisher } & \multicolumn{2}{c}{ Pied kingfisher } \\
\cline { 2 - 5 } & $\mathbf{( \% )}$ of Used & Average height $(\mathbf{m})$ & $\mathbf{( \% )}$ of Used & Average height (m) \\
\hline Fence & 11.67 & $4.85 \pm 2.16(\mathrm{n}=15)$ & 53.43 & $3.32 \pm 1.70(\mathrm{n}=39)$ \\
Tree & 68.89 & $15.55 \pm 7.38(\mathrm{n}=53)$ & 22.765 & $9.3 \pm 3.67(\mathrm{n}=32)$ \\
Bamboo & 16.67 & $4.83 \pm 1.16(\mathrm{n}=20)$ & 19.03 & $4.83 \pm 1.16(\mathrm{n}=20)$ \\
Wire & 2.78 & $5.5 \pm 0.41(\mathrm{n}=4)$ & 4.78 & $5.5 \pm 0.41(\mathrm{n}=4)$ \\
\hline
\end{tabular}

$\mathrm{n}$ : number of observation of the perching places (fence, tree, bamboo and wire) 
Variation of the perching height: The perching height used by stork-billed kingfisher was 1 to $30 \mathrm{~m}$ (mean $11.03 \pm 7.76 \mathrm{~m}, \mathrm{n}=92$ ) and it was 1 to $15 \mathrm{~m}$ (mean $5.74 \pm 3.58 \mathrm{~m}, \mathrm{n}=95$ ) in case of pied kingfisher that statistically differed significantly between the two species $(\mathrm{t}=6.02$, $\mathrm{df}=185, \mathrm{p}=9.09 \mathrm{E}-09)$. The average height of the fences used by stork-billed kingfisher was 1 to $8 \mathrm{~m} \mathrm{(4.85 \pm}$ $2.16 \mathrm{~m}, \mathrm{n}=15)$ and it was 1 to $6.5 \mathrm{~m}(3.32 \pm 1.70 \mathrm{~m}, \mathrm{n}=39)$ for pied kingfisher, that differed significantly between the two species $(t=2.46, d f=21, p=0.02)$ (Table 2; Fig. 9). The height of perching place in the tree was 4 to $30 \mathrm{~m}$ (mean $15.55 \pm 7.38 \mathrm{~m}, \mathrm{n}=53$ ) for stork-billed kingfisher and 3.5 to $15 \mathrm{~m}$ (mean $9.3 \pm$ $3.67 \mathrm{~m}, \mathrm{n}=32$ ) for pied kingfisher (Table 2; Fig. 9). On the other hand, the perching height of bamboo and wire used by both species were same and that was 3 to $6.5 \mathrm{~m}$ (mean $4.83 \pm 1.16 \mathrm{~m}, \mathrm{n}=20$ ) and 5 to 6 (mean $5.5 \pm 0.41 \mathrm{~m}, \mathrm{n}=$ 4) respectively (Table 2; Fig. 9). Yihune and Bekele (2010) found the pied kingfishers typically used on perching sites with a height of 1-5 $\mathrm{m}$ in the Lake Hora Arsedi, Debrezeit, Ethiopia; whereas Monadjem et al. (1994) observed pied kingfishers spending time on perching sites usually having a length of 2-4 $\mathrm{m}$ high in the Kruger National Park. Bonnington et al. (2008) reported that the pied kingfishers preferred the foraging areas with higher perch-sites; and deeper and wider water bodies.

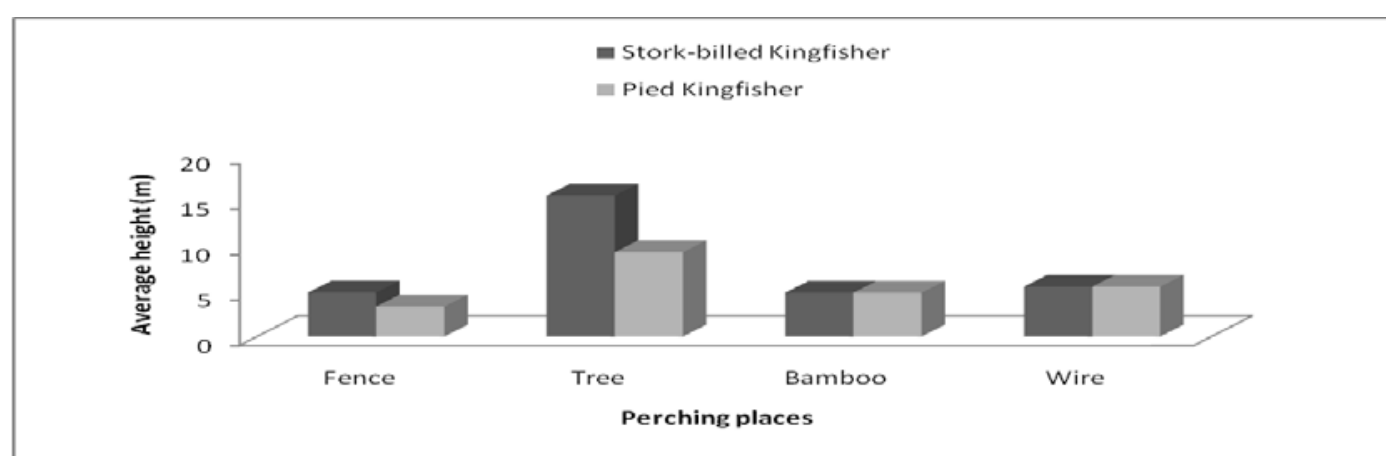

Fig. 9. Average height (m) of perching places used by two species of kingfishers at the CUC.

Preferred tree species: The both kingfisher preferred 18 species of small, medium and large trees during resting, perching, calling and feeding (Table 3), of which stork-billed kingfisher usually preferred trees with larger and medium heights but occasionally they also used the smaller ones; whereas pied kingfisher generally preferred the smaller trees and periodically they also used the medium ones. 
Table 3. List of tree species preffered by two species of kingfishers at the CUC.

\begin{tabular}{|c|c|c|}
\hline Family & Scientific Name & Local Name \\
\hline Anacardiaceae & Mangifera indica & Aam \\
\hline Annonaceae & Polyalthia longifolia & Debdaru \\
\hline Arecaceae & Cocos nucifera & Coconut \\
\hline Arecaceae & Phoenix sp. & Date Palm \\
\hline Dipterocarpaceae & Dipterocarpus spp. & Garjan \\
\hline Fabaceae & Acacia moniliformis & Akashmoni, \\
\hline Fabaceae & Cassia fistula & Bandar lathi/Sonalu \\
\hline Fabaceae & Albizzia spp. & Koroi \\
\hline Fabaceae & Butea monosperma & Palash \\
\hline Lamiaceae & Tectona grandis & Shegun \\
\hline Lythraceae & Lagerstroemia speciosa & Jarul \\
\hline Malvaceae & Salmalia spp. & Shimul \\
\hline Moraceae & Ficus benghalensis & Bot \\
\hline Moraceae & Ficus sp. & Fig tree \\
\hline Moraceae & Artocarpus heterophyllus & Kanthal \\
\hline Musaceae & Musa spp. & Banana tree \\
\hline Myrtaceae & Syzygium cumini & Jam \\
\hline Poaceae & Bambusa sp. & Common Bamboo \\
\hline
\end{tabular}

Variation of tree height: Three categories of trees (large, medium and small) of different species were observed to use by both species of kingfishers. Overall, the large trees were 20 to $30 \mathrm{~m}$ (mean $24.77 \pm 3.30 \mathrm{~m}, \mathrm{n}=16$ ) in height, while medium were 10 to $19.99 \mathrm{~m}$ (mean $13.73 \pm 2.60 \mathrm{~m}, \mathrm{n}=38$ ) and small 3.5 to $9.99 \mathrm{~m}$ (mean $6.56 \pm 1.83 \mathrm{~m}, \mathrm{n}=31$ ) for both kingfishers. Stork-billed kingfisher used 20 to $30 \mathrm{~m}$ (mean $24.77 \pm 3.30 \mathrm{~m}, \mathrm{n}=16$ ) height in large trees, 10 to 19.6 $\mathrm{m}$ (mean $14.43 \pm 2.88 \mathrm{~m}, \mathrm{n}=23$ ) medium and 4 to $9 \mathrm{~m}$ (mean $6.84 \pm 1.72 \mathrm{~m}, \mathrm{n}$ $=14$ ) small trees (Table 4; Fig. 10). On the other hand, pied kingfisher usually did not use large trees but they only used the medium and small trees, which were 10 to $15 \mathrm{~m}$ in height (mean $12.66 \pm 1.66 \mathrm{~m}, \mathrm{n}=15$ ) and 3.5 to $9.6 \mathrm{~m}$ (mean $6.34 \pm 1.93 \mathrm{~m}, \mathrm{n}=17$ ) respectively (Table 4; Fig. 10). 
Table 4. Variation of average height $(\mathrm{m})$ of trees used by two species of kingfishers at the CUC.

\begin{tabular}{lcccc}
\hline \multirow{2}{*}{$\begin{array}{c}\text { Types of } \\
\text { Trees }\end{array}$} & \multicolumn{2}{c}{ Stork-billed kingfisher } & \multicolumn{2}{c}{ Pied kingfisher } \\
\cline { 2 - 5 } & Height (m) & Average height (m) & Height (m) & Average height (m) \\
\hline Smaller & $4-9$ & $6.84 \pm 1.72(\mathrm{n}=14)$ & $3.5-9.6$ & $6.34 \pm 1.93(\mathrm{n}=17)$ \\
Medium & $10-19.6$ & $14.43 \pm 2.88(\mathrm{n}=23)$ & $10-15$ & $12.66 \pm 1.66(\mathrm{n}=15)$ \\
Larger & $20-30$ & $24.77 \pm 3.30(\mathrm{n}=16)$ & - & - \\
\hline
\end{tabular}

$\mathrm{n}$ : number of observation of different trees

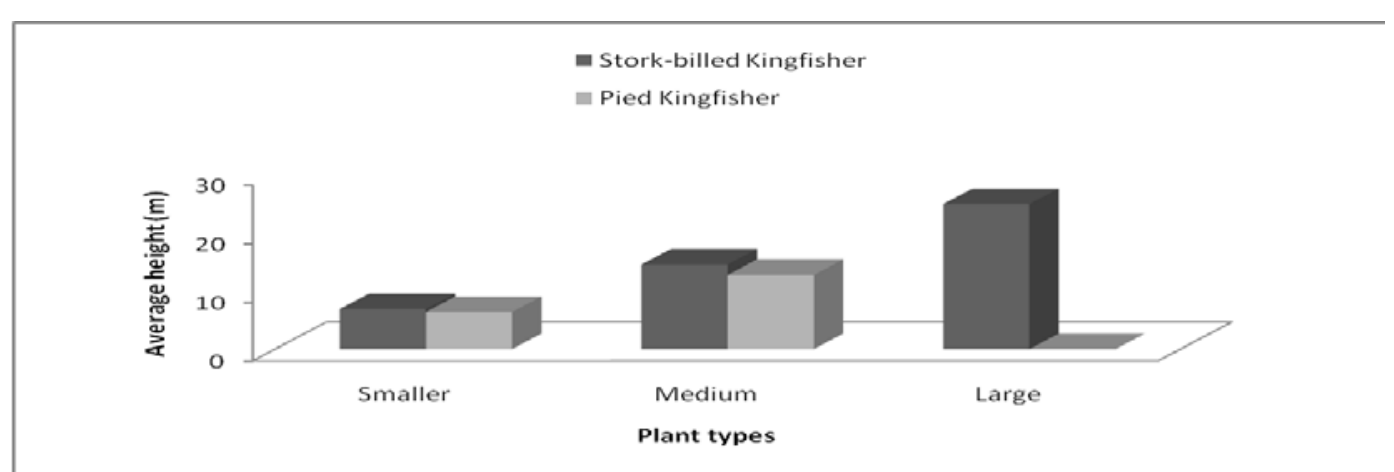

Fig. 10. Average height (m) of trees used by two species of kingfishers at the CUC.

Interaction with other vertebrates: The kingfishers usually reside in a wide range of habitats including rivers and lakes but over half of the world's species occur in forests and forested streams (Woodall 2001). Food partitioning generally plays an important role in facilitating the co-existence of sympatric species and three main factors (abundance of food, body size and breeding systems) help in the potential mechanisms of food partitioning among the sympatric species (Garcia and Arroyo 2005). A total of 48 species of wild-animals from four classes (Amphibia, Reptilia, Aves and Mammalia) were recorded during the study period (Appendix 1), of which the birds were dominant species (75\%; Fig. 11).

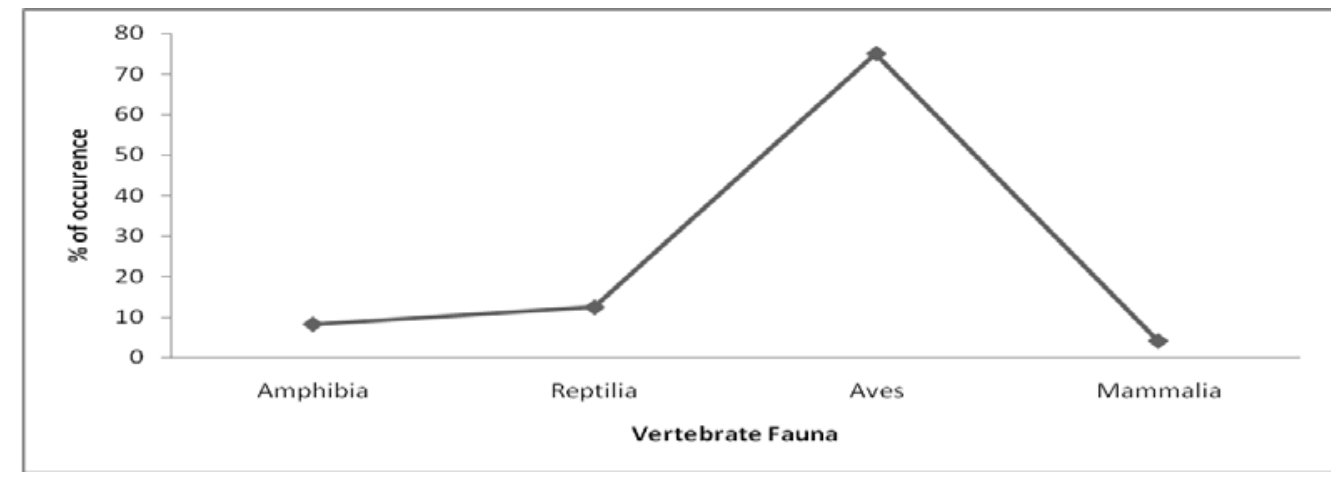

Fig. 11. Occurrence of the vertebrates in surrounding habitats of kingfishers at the CUC. 
Water condition and quality of the aquatic bodies: Slow water current was observed in the streams whereas the lakes and ponds were remained relatively stable, still or standing. Three important parameters (temperature, $\mathrm{pH}$ and turbidity) were measured to assess the water quality (Table 5). The average maximum temperature $31.1{ }^{\circ} \mathrm{C}$ was recorded in lake and the minimum $29.25{ }^{\circ} \mathrm{C}$ was in pond, whereas the highest (11.5) $\mathrm{pH}$ examined in stream and the lowest (10.35) in pond (Table 5). On the other hand, the high turbidity $41.5 \mathrm{~cm}$ was calculated in lake and the low $16.25 \mathrm{~cm}$ in stream (Table 5).

Tabel 5. Parametrs of wetlands used by the two species of kingfishers at the CUC.

\begin{tabular}{lcccccc}
\hline \multirow{2}{*}{$\begin{array}{c}\text { Water } \\
\text { Bodies }\end{array}$} & \multicolumn{2}{c}{ Temperature $\left({ }^{\circ} \mathbf{C}\right)$} & \multicolumn{2}{c}{ pH } & \multicolumn{2}{c}{ Turbidity (cm) } \\
\cline { 2 - 7 } & Range & Average & Range & Average & Range & Average \\
\hline Stream & $29-32$ & $30.5 \pm 2.12(\mathrm{n}=2)$ & $11.0-11.1$ & $11.5 \pm 0.07(\mathrm{n}=2)$ & $10.2-22.3$ & $16.25 \pm 8.56(\mathrm{n}=2)$ \\
Lake & $29-33$ & $31.0 \pm 2.83(\mathrm{n}=2)$ & $10.8-11.1$ & $10.95 \pm 0.21(\mathrm{n}=2)$ & $33.5-45.9$ & $41.5 \pm 11.31(\mathrm{n}=2)$ \\
Pond & $29-29.5$ & $29.25 \pm 0.35(\mathrm{n}=2)$ & $10.1-10.6$ & $10.35 \pm 0.35(\mathrm{n}=2)$ & $11.0-24.5$ & $17.8 \pm 9.62(\mathrm{n}=2)$ \\
Overall & $29-33$ & $30.25 \pm 1.78(\mathrm{n}=6)$ & $10.1-11.1$ & $10.78 \pm 0.39(\mathrm{n}=6)$ & $10.2-45.9$ & $\begin{array}{c}24.57 \pm 13.64 \\
(\mathrm{n}=6)\end{array}$ \\
\hline
\end{tabular}

n: number of observation of aquatic bodies (stream, lake and pond)

Soil type of the study area: The soil samples were collected from both feeding and breeding grounds of kingfishers of which the feeding ground was used by four species (common kingfisher, white-throated kingfisher, stork-billed kingfisher and pied kingfisher) found at the CUC but the breeding spots were used by three species (white-throated kingfisher, stork-billed kingfisher and pied kingfisher). The soil texture of feeding ground was both sandy and loamy sandy in sample-1 (feeding ground - lake) and sample-3 (feeding ground - stream); whereas in sample-2 (nesting spot) the soil texture was sandy (Table 6). Clay was the highest $(6.45 \%)$ in sample-3 (feeding ground - stream) and the lowest $(2.11 \%)$ in sample-2 (nesting spot); slit was the maximum $(11.82 \%)$ in sample-3 (feeding ground - stream) and the minimum $(2.10 \%)$ in sample-1 (feeding ground - lake), whereas sand was the most $(95.79 \%)$ in sample-2 (nesting spot) and the least $(81.73 \%)$ in sample-3 (feeding ground- stream) (Table 6).

Table 6. Soil composition in feeding and nesting sites of kingfishers at the CUC.

\begin{tabular}{lcccc}
\hline \multicolumn{1}{c}{ Soil Type } & Clay (\%) & Slit (\%) & Sand (\%) & Texture \\
\hline Sample-1 (Feeding ground) & 4.21 & 2.10 & 93.69 & Sand \\
Sample-2 (Nesting spot) & 2.11 & 2.11 & 95.79 & Sand \\
Sample-3 (Feeding ground) & 6.45 & 11.82 & 81.73 & Loamy sand \\
\hline
\end{tabular}


The kingfishers have a significant role in ecosystem and human culture due to their habitat preference and food habit. The habitat loss is one of the major causes of declining the population of stork-billed and pied kingfishers in Bangladesh. Consequently, habitat analysis can assist to identify their preferred and used environmental factors for their sustainability in nature.

Acknowledgements: We express sincere gratitude to Mr. Kanak Choudhury, Assistant Professor, Department of Statistics, University of Chittagong, Chittagong, for his kind help in statistical analysis during the research work. The authors are also grateful to Mr. Sajal Roy, Assistant Professor, Department of Soil Science, University of Chittagong, Chittagong, for his support in soil analysis at the present study.

\section{LITERATURE CITED}

AHSAN, M. F. and KHANOM, N. 2005. Birds of the Chittagong University Campus, Chittagong. The Chittagong Univ. J. Sci. 29 (1): 77-88.

ALI, S. 1996. The book of Indian Birds. Twelfth Revised and Enlarged edition. Bombay Natural History Society, Oxford University Press, Mumbai. 354 pp.

ALI, S. and RIPLEY, S. D. 1970. Handbook of the birds of India and Pakistan. Oxford Univ. Press, Bombay, London, New York. Vol. 4, 263 pp.

ALTMANN, J. 1974. Observational study of behaviour: sampling method. Behav. 49: 222267.

BEGBIE, A. 1906. The stork-billed kingfisher (Pelargopsis gurial) at Cawnpore. J. Bombay Nat. Hist. Soc. 17(1): 248 - 249.

BONNINGTON, C., WEAVER, D. and FANNING, E. 2008. The habitat preference of four kingfisher species along a branch of the Kilombero River, Southern Tanzania. Afr. J. Ecol. 46: 424-427.

CODY, M. L. 1985. Habitat selection in grassland and open-country birds. Physiol. Ecol. Ser.: 191-226.

DOUTHWAITE, R. J. 1982. Changes in Pied Kingfisher (Ceryle rudis) feeding related to endosulfan pollution from tsetse fly control operations in the Okavango Delta, Botswana. J. Applied Eco. 19: 133-141.

FRY, C. H.; FRY, K.; and HARRIS, A. 1992. Kingfishers, bee-eaters and rollers. Christopher Helm. 324 pp.

GARCIA, J. and ARROYO, B. 2005. Food niche differentiation in sympatric Hen Circus cyaneus and Montagu's Harriers Circus pygargus. Ibis. 147:144-154.

GRIMMETT, R., INSKIP, C. and INSKIP, T. 1999. Pocket guide to the birds of the Indian Subcontinent. Oxford Univ. Press, New Delhi, India. 384 pp.

HOCKEY, P. A. R., DEAN, W. R. J. and RYAN, P. G. (eds). 2005. Roberts - Birds of southern Africa, VIIth ed. The Trustees of the John Voelcker Bird Book Fund, Cape Town. 
IMAMUL HUQ, S. M., and ALAM, M. D. (eds.). 2005. A Handbook on Analyses of Soil, Plant and Water. BACER-DU, University of Dhaka, Bangladesh, xxii+246 pp.

ISLAM, A. T. N. T., CHOWDHURY, H. S. S., HOQUE, A. K. M. M. and MALIK, S. A. 1979. Detailed soil survey of Chittagong University campus, Chittagong. 1974. Preliminary edition. Department of the peoples Republic Bangladesh. 207 pp.

ISLAM, M. A. and KAMRUZZAMAN, M. 2008. Ceryle rudis. Pp. 78-79. In: Siddiqui, K.U., Islam, M. A., Kabir, S. M. H., Ahmed, M., Ahmed, A. T. A., Rahman, A. K. A., Haque, E. U., Ahmed, Z. U., Begum, Z. N. T., Hassan, M. A., Khondker, M. and Rahman, M. M. (eds.) 2008. Encyclopedia of flora and fauna of Bangladesh, vol. 26. Birds. Asiatic Society of Bangladesh. Dhaka. 662 pp.

ISLAM, M. A. and KAMRUZZAMAN, M. 2008. Pelargopsis capensis. Pp. 73-74. In: Siddiqui, K.U., Islam, M. A., Kabir, S. M. H., Ahmed, M., Ahmed, A. T. A., Rahman, A. K. A., Haque, E. U., Ahmed, Z. U., Begum, Z. N. T., Hassan, M. A., Khondker, M. and Rahman, M. M. (eds.) 2008. Encyclopedia of flora and fauna of Bangladesh, vol. 26. Birds. Asiatic Society of Bangladesh. Dhaka. 662 pp.

JOHN, C. 1986. The new observer's book of pond life. Frederick Warne. p. 460.

KHAN, M. A. R. 1982. Wildlife of Bangladesh: a checklist. University of Dhaka, Dhaka, Bangladesh. $173 \mathrm{pp}$.

KULSHRESHTHA, M. and VYAS, R. 1989. Stork-billed kingfisher in Eastern Rajasthan, Newsletter for Birdwatchers. 29: 9-10: 11.

LIBOIS, R. and LAUDELOUT, A. 2004. Food niche segregation between the Malachite Kingfisher, Alcedo cristata, and the Pied Kingfisher, Ceryle rudis, at Lake Nokoua, Benin., Ostrich, 75(1 and 2): 32 - 38.

MEINZER, O. E. 1923. Outline of ground-water hydrology, with definitions. Washington, DC: USGS. Water Supply Paper. 494 pp.

MONADJEM, A. 1996. Habitat associations of birds along the Sabie River, South Africa. African J. Eco. 34: 75-78.

MONADJEM, A., OWEN-SMiTH, R., and Kemp, A. 1994. Perch-site selection by three species of kingfisher. Ostrich. 65: 342-343.

WILliAMS, P., WHITFIELD, M., BIGGS, J., BRAY, S., FOX, G., NICOLET, P., SEAR, D. 2004. Comparative biodiversity of rivers, streams, ditches and ponds in an agricultural landscape in Southern England. Biol. Conserv. 115 (2): 329-341.

WOODALL, P. 2001. Family Alcedinidae (Kingfishers). pp. 103-187. In: del Hoyo, Josep; Elliott, Andrew; Sargatal, Jordi. Handbook of the Birds of the World. Volume 6, Mousebirds to Hornbills. Barcelona: Lynx Edicions.

YIHUNE, M. and BEKELE, A. 2010. Diet activity of pied kingfisher (Ceryle rudis) in Lake Hora Arsedi, Debrezeit. Ethiop. J. Biol. Sci. 9(2): 117-125. 


\begin{tabular}{|c|c|c|c|}
\hline Common Name & Scientific Name & Family & Class \\
\hline Asian Common Toad & Duttaphrynus melanostictus & Bufonidae & \\
\hline Skipper Frog & Euphlyctis cyanophlyctis & Dicroglossidae & \\
\hline Cricket Frog & Fejervarya lemnocharis & Dicroglossidae & Amphibia \\
\hline Indian Bull Frog & Hoplobatrachus tigerinus & Dicroglossidae & \\
\hline $\begin{array}{l}\text { South Asian Giant House } \\
\text { Gecko }\end{array}$ & Gekko gecko & Gekkonidae & \\
\hline House Lizard & Hemidactylus sp. & Gekkonidae & Reptilia \\
\hline Spotted House Lizard & H. frenatus & Gekkonidae & \\
\hline Common Skink & Eutropis carinatus & Scincidae & \\
\hline Bengal Monitor & Varanus bengalensis & Varanidae & \\
\hline Checkered Keel back & Xenochrophis sp & Colubridae & \\
\hline Common Kingfisher & Alcedo atthis & Alcedinidae & \\
\hline White-throated Kingfisher & Halcyon smyrnensis & Halcyonidae & \\
\hline Stork-billed Kingfisher & Pelargopsis capensis & Halcyonidae & \\
\hline Pied Kingfisher & Ceryle rudis & Cerylidae & \\
\hline Green Bee-eater & Merops orientalis & Meropidae & \\
\hline Blue-tailed Bee-eater & M. philippinus & Meropidae & \\
\hline Chestnut-headed Bee-eater & M. leschenaultia & Meropidae & \\
\hline Indian Cuckoo & Cuculus micropterus & Cuculidae & \\
\hline Green-billed Malkoha & Phaenicophaeus tristis & Cuculidae & \\
\hline Lesser Coucal & Centropus sinensis & Centropidae & \\
\hline Greater Coucal & C. bengalensis & Centropidae & \\
\hline Rose-ringed Parakeet & Psittacula krameri & Psittacidae & \\
\hline Asian Palm Swift & Cypsiurus balasiensis & Apodidae & Aves \\
\hline Spotted Owlet & Athene brama & Strigidae & \\
\hline Rock Pigeon & Columba livia & Columbidae & \\
\hline Spotted Dove & Streptopelia chinensis & Columbidae & \\
\hline White-breasted Water-hen & Amaurornis phoenicurus & Rallidae & \\
\hline Black Kite & Milvus migrans & Accipitridae & \\
\hline Little Egret & Egretta garzetta & Ardeidae & \\
\hline Cattle Egret & Bubulcus ibis & Ardeidae & \\
\hline Indian Pond Heron & Ardeola grayii & Ardeidae & \\
\hline
\end{tabular}




\begin{tabular}{|c|c|c|c|}
\hline Common Name & Scientific Name & Family & Class \\
\hline House Crow & Corvus splendens & Corvidae & \\
\hline Jungle Crow & C. macrorhynchos & Corvidae & \\
\hline Black-headed Oriole & Oriolus xanthornus & Corvidae & \\
\hline White-throated Fantail & Rhipidura albicollis & Corvidae & \\
\hline Black Drongo & Dicrurus macrocercus & Corvidae & \\
\hline Magpie Robin & Copsychus saularis & Muscicapidae & \\
\hline Golden-back Woodpecker & Dinopium benghalense & Picidae & \\
\hline Common Hoopoe & Upupa epops & Upupidae & \\
\hline Common Myna & Acridotheres tristis & Sturnidae & \\
\hline Pied Myna & Srurnus contra & Sturnidae & \\
\hline Jungle Myna & A. cinereus & Sturnidae & \\
\hline Grey-headed Mayna & Sturnus malabaricus & Sturnidae & \\
\hline Red-vented Bulbul & Pycnonotus cafer & Pycnonotidae & \\
\hline House Sparrow & Passer domisticus & Passeridae & \\
\hline Little Cormorant & Phalacrocorax niger & Phalacrocoracidae & \\
\hline Irrawaddy Squirrel & Callosciurus pygerythrus & Sciuridae & Mammalia \\
\hline Common House Rat & Rattus rattus & Muridae & \\
\hline
\end{tabular}

